\title{
Studies on the Anti-Inflammatory Properties of Various extracts of Hippophae rhamnoide
}

\author{
M Amin Mir ${ }^{1 *}$, Bilal Ahmad Mir ${ }^{3}$, Dhyal Singh ${ }^{2}$ and Zainab Rao $^{3}$ \\ ${ }^{1}$ Department of Chemistry, Uttarakhand Technical University, India \\ ${ }^{2}$ Department of Zoology, Uttaranchal College of Bio-medical sciences and Hospital, India \\ ${ }^{3}$ Department of Microbiology, Uttaranchal College of Bio-medical sciences and Hospital, India
}

Submission: January 26, 2017; Published: February 28, 2017

*Corresponding author: M Amin Mir, Department of Chemistry, Uttarakhand Technical University, 169 Ambedkar colony DL road Dehradun (Uttarakhand), India, Tel: 09897635334; Email: mohdaminmir@gmail.com

\begin{abstract}
The plant Hippophae rhamnoide have been analysed for the anti-inflammatory property and it had been found that the concerned plant posses a good potential against inflammation. Among the plant parts analysed, the fruit extracts have been found to posses' high potential against inflammation followed by leaf extracts and root extracts posses the least effect against inflammation. Three different solvents have been used for extraction purpose viz, Dichloromethane, methanol and water. Among the various solvent extracts, the water extracts of all the three plant parts posses much more anti-inflammatory property followed by methanolic extracts, and lesser potential was noticed for DCM extracts.
\end{abstract}

Keywords: Hippophae rhamnoide; Anti-inflammatory; HRBC; Membrane hemolysis

Abbreviations: SBT: Sea Buckthorn; NO: Nitric Oxide; PG: Prostaglandin; HRBC: Human Red Blood Cells

\section{Introduction}

India and China are two of the largest countries in Asia which have the richest arrays of registered and relatively well known medicinal plants. India endowed with a rich wealth of medicinal plants is unique in the use of plants/plant parts by all sections of people either directly as folk medicine directly or indirectly in the pharmaceutical preparations of modern medicine. The knowledge of medicinal plants has been accumulated in the course of many centuries based on different systems of medicines such as Ayurveda, Unani and Siddha in India. Rigveda and Atharveda which date back to 2000-1000 BC and several post Vedic treatises such as Charakasamhita (100 AD), Sushruthasamhitha (100-800 AD) and Dhanwanthari Nighantu (1200 AD) are the important ancient sources of information on medicinal plants. Sixty percent of the world population and $80 \%$ of the population in developing countries depend on traditional medicine, mostly plant drugs, for their primary health care needs. Out of the total known number of medicinal plants from India, approximately $46 \%$ are from the Himalayas. Out of the total medicinal plant species, 62 species of medicinal plants are endemic to the Himalayas and 208 species have extend their distribution towards adjacent areas and are, therefore considered as near endemic.

Over 200 species of Himalayan medicinal plants are consumed as raw, roasted, boiled, fried, cooked, or they are used in the form of oil, spices, jams or pickles. Sea Buckthorn (Hippophae rhamnoides L.) and its relatives in the family Eleaegnaceae are shrubs and small trees having berries containing compounds with high nutritional and medicinal value Singh, V [1], Kalia RK et al. [2]. Sivaraj Anbarasu showed Sea Buckthorn (SBT) is distributed in India and the plant parts are used traditionally for several ailments. Medicinally, it has been proven to possess various pharmacological activities such as antioxidant, antimicrobial, antifungal, metabolic disorders, immune-stimulatory activity, hepato-protectant and anticancer activity. Yan-Jun Xu et.al [3] showed Sea buckthorn is a natural source of vitamins and several other bioactive compounds like carotenoids and flavonoids, which have been known to lower cholesterol, platelet aggregation, blood pressure and 
blood sugar. In addition, sea buckthorn is a well known herb in treating tumors, stomach ulcers, skin diseases and arsenic poisoning. Alam Zeb [4] showed that Sea buckthorn juice is one of the imperative product obtained from the sea buckthorn berries, is commercially very important. The juice from the plant provides a nutritious beverage, high in suspended solids, and very high in vitamins especially in vitamin $\mathrm{C}$ and carotenoids. It contains many important nutrients and bioactive substances including vitamins, fatty acids, free amino acids and elemental components.

\section{Materials and Method for anti-inflammatory analysis}

The study, anti-inflammatory properties of "Hippophae rhamnoides" were carried out. All the chemicals and reagents used were of analytical grade. The concerned plant namely Hippophae rhamnoides was collected from Ladakh region of J \& K. Dextrose, Sodium citrate, Citric acid, Sodium chloride, Phosphate buffer, Hypo saline, were purchased from Hi-media, methanol used were of analytical grade.

\section{Experiment Work}

\section{Study area and plant collection}

The concerned plant was collected from the Ladakh region of J \& K. The plant parts were segregated shade dried and powdered in mixture. The powder was used for experiment.

\section{Extraction}

50 gms of the plant root, stem and leaf powder were weighed separately and accurately and then extracted in a Soxhlet Apparatus using thimble in order to get the best extract. Various solvents were used depending upon their polarity index with increasing polarity (DCM, Methanol and Water).

I.Extraction A: The sample was extracted with a particular solvent (DCM) in a Soxhlet apparatus for a required period. After the Extraction with Petroleum ether, the extract solution was subjected to filtration to remove the residue from extract. The filtrate was then collected and evaporated to remove the volatile solvent to its $1 / 4^{\text {th }}$ volume on water bath at a suitable temperature. The whole filtrate was then made in solid form (powdered) after being kept in an oven at 40-600C. The residue was collected, and subjected to further extraction process.

II.Extraction B: The residue was then extracted with Methanol in a same manner as mentioned above, in extraction A.

III.Extraction C: The residue from extract B was subjected to Water extraction by decoction technique. In this technique the extract was dissolved in $500 \mathrm{ml}$ of water. The whole solution was heated over water bath to remove all the water from the extract. Finally additional $500 \mathrm{ml}$ of water was added to the extract, the extracted solution was finally evaporated to remove nearly 250 $\mathrm{ml}$ of water. The obtained solution was subjected to filtration and then the filtrate was evaporated to remove nearly $1 / 4$ th of its volume. Finally the extract was dried in an oven at a temperature range 30-500C.

\section{Anti-inflammatory activity of Hippophae rhamnoides plant extracts}

Inflammation is a complex physiological process mediated by a variety of signaling molecules produced by leukocytes, macrophages, and mast cells. Inflammation is a tissue response to injury characterized by increased blood flow to the tissue causing increased temperature, redness, swelling, and pain. Macrophages play important role in inflammatory diseases through the release of inflammatory mediators such as nitric oxide (NO), prostaglandin (PG) E2, and pro-inflammatory cytokines.

\section{Preparation of human red blood cells (HRBC) suspension}

Fresh whole human blood was collected and mixed with equal volume of sterilized Alsever solution (2\% dextrose, $0.8 \%$ sodium citrate, $0.05 \%$ citric acid and $0.42 \%$ sodium chloride in water). The blood was centrifuged at $3000 \mathrm{rpm}$ for $10 \mathrm{~min}$ and packed cells were washed three times with isosaline $(0.85 \%, \mathrm{pH}$ 7.2). The volume of the blood was measured and reconstituted as $10 \% \mathrm{v} / \mathrm{v}$ suspension with isosaline Sakat S, Juvekar AR et al. [5], Govindappa M et al. [6].

\section{Heat induced hemolysis}

The principle involved here is stabilization of human red blood cell membrane by hypotonicity induced membrane lysis. The assay mixture composes $1 \mathrm{ml}$ phosphate buffer [pH 7.4, 0.15 $\mathrm{M}$ ], $2 \mathrm{ml}$ hypo saline [0.36 \%], $0.5 \mathrm{ml} \mathrm{HRBC}$ suspension [ $10 \% \mathrm{v} / \mathrm{v}$ ] with various concentrations of plant extracts and standard drug diclofenac sodium of various concentrations (50, 100, 200, 300, $400,500 \mu \mathrm{g}$ ) and control (distilled water in place of hyposaline to produce $100 \%$ hemolysis) were incubated at $37 \mathrm{oC}$ for $30 \mathrm{~min}$ and then centrifuged. The hemoglobin content in the suspension was estimated using spectrophotometer at $560 \mathrm{~nm}$ by using Patel DK, Prasad SK, Kumar R, Hemalatha S. - 2012 method.

The percentage of hemolysis of HRBC membrane can be calculated as follows:

$\%$ Hemolysis $=($ Absorbance of Test Sample $/$ Absorbance of Control) x 100

The percentage of HRBC membrane stabilization can be calculated as follows:

$\%$ Protection $=100-[$ (Absorbance by Test sample $/$ Absorbance by Control) $x$ 100]

\section{Observation and Results}

The anti-inflammatory properties of various extracts of Hippophae rhamnoides have been carried out by the lysis of cells which was carried out by hypotonicity. The percentage hemolysis and correspondingly the percentage stabilization against the membrane hemolysis were carried out. The percentage stabilization gets increased against the concentration increase. 


\section{Anti-inflammatory properties of leaf, fruit and root extracts of Hippophae rhamnoides}

The anti-inflammatory properties of Leaf, Fruit and Root extracts have been carried out and it was found that the reference compound (Diclofenac sodium) have been found to posses the highest \% stabilization as shown in all tables and figures (Tables 1-9) (Figures 1-18). Among the plant extracts it has been found that methanolic extract of fruit posses the highest percentage stabilization followed by water extract of fruit, methanolic extract of root, water extract of leaf, ethanolic Table 1: Report of anti-inflammatory effect of DCM extract of leaf of Hippophae rhamnoides and standard on HRBC membrane hemolysis and membrane stabilization.

\begin{tabular}{|c|c|c|c|c|}
\hline $\begin{array}{c}\text { Conc. of Standard/ } \\
\text { Plant Extract }(\boldsymbol{\mu l} / \mathbf{m l})\end{array}$ & \% Hemolysis & \% Stabilisation & $\begin{array}{c}\text { \% Hemolysis of } \\
\text { Diclofenac sodium }\end{array}$ & $\begin{array}{c}\text { \% Stabilisation of } \\
\text { Diclofenac sodium }\end{array}$ \\
\hline 0.5 & 41.56 & 58.44 & 47.97 & 50.9 \\
\hline 1.0 & 40.41 & 59.59 & 27.89 & 64.6 \\
\hline 1.5 & 39.31 & 60.69 & 15.63 & 78.97 \\
\hline 2.0 & 38.65 & 61.35 & 11.54 & 87.99 \\
\hline 2.5 & 32.65 & 67.35 & 6.44 & 95.52 \\
\hline
\end{tabular}

Table 2: Report of anti-inflammatory effect of Methanolic extract of leaf of Hippophae rhamnoides and standard on HRBC membrane hemolysis and membrane stabilization.

\begin{tabular}{|c|c|c|c|c|}
\hline $\begin{array}{c}\text { Conc. of Standard/ } \\
\text { Plant Extract }(\boldsymbol{\mu l} / \mathbf{m l})\end{array}$ & \% Hemolysis & \% Stabilisation & $\begin{array}{c}\text { \% Hemolysis of } \\
\text { Diclofenac sodium }\end{array}$ & $\begin{array}{c}\text { \% Stabilisation of } \\
\text { Diclofenac sodium }\end{array}$ \\
\hline 0.5 & 41.49 & 58.51 & 47.97 & 50.9 \\
\hline 1.0 & 39.39 & 60.61 & 27.89 & 64.6 \\
\hline 1.5 & 34.61 & 65.39 & 15.63 & 78.97 \\
\hline 2.0 & 32.88 & 67.12 & 11.54 & 87.99 \\
\hline 2.5 & 25.17 & 74.83 & 6.44 & 95.52 \\
\hline
\end{tabular}

Table 3: Report of anti-inflammatory effect of water extract of leaf of Hippophae rhamnoides and standard on HRBC membrane hemolysis and membrane stabilization.

\begin{tabular}{|c|c|c|c|c|}
\hline $\begin{array}{c}\text { Conc. of Standard/ } \\
\text { Plant Extract }(\boldsymbol{\mu l} / \mathbf{m l})\end{array}$ & \% Hemolysis & \% Stabilisation & $\begin{array}{c}\text { \% Hemolysis of } \\
\text { Diclofenac sodium }\end{array}$ & $\begin{array}{c}\text { \% Stabilisation of } \\
\text { Diclofenac sodium }\end{array}$ \\
\hline 0.5 & 21.14 & 78.86 & 47.97 & 50.9 \\
\hline 1.0 & 20.00 & 80.00 & 27.89 & 78.97 \\
\hline 1.5 & 20.01 & 79.99 & 15.63 & 87.99 \\
\hline 2.0 & 18.92 & 81.08 & 11.54 & 95.52 \\
\hline 2.5 & 18.11 & 81.89 & 6.44 & \\
\hline
\end{tabular}

Table 4: Report of anti-inflammatory effect of DCM extract of Fruit of Hippophae rhamnoides and standard on HRBC membrane hemolysis and membrane stabilization.

\begin{tabular}{|c|c|c|c|c|}
\hline $\begin{array}{c}\text { Conc. of Standard/ } \\
\text { Plant Extract }(\boldsymbol{\mu l} / \mathbf{m l})\end{array}$ & \% Hemolysis & \% Stabilisation & $\begin{array}{c}\text { \% Hemolysis of } \\
\text { Diclofenac sodium }\end{array}$ & $\begin{array}{c}\text { \% Stabilisation of } \\
\text { Diclofenac sodium }\end{array}$ \\
\hline 0.5 & 39.88 & 60.12 & 47.97 & 50.9 \\
\hline 1.0 & 37.17 & 60.83 & 27.89 & 78.6 \\
\hline 1.5 & 35.54 & 62.46 & 15.63 & 87.99 \\
\hline 2.0 & 34.66 & 63.34 & 6.44 & 95.52 \\
\hline
\end{tabular}




\section{Journal of Pharmacology \& Clinical Research}

Table 5: Report of anti-inflammatory effect of Methanolic extract of fruit of Hippophae rhamnoides and standard on HRBC membrane hemolysis and membrane stabilization.

\begin{tabular}{|c|c|c|c|c|}
\hline $\begin{array}{c}\text { Conc. of Standard/ } \\
\text { Plant Extract }(\boldsymbol{\mu l} / \mathbf{m l})\end{array}$ & \% Hemolysis & \% Stabilisation & $\begin{array}{c}\text { \% Hemolysis of } \\
\text { Diclofenac sodium }\end{array}$ & $\begin{array}{c}\text { \% Stabilisation of } \\
\text { Diclofenac sodium }\end{array}$ \\
\hline 0.5 & 20.14 & 79.86 & 47.97 & 50.9 \\
\hline 1.0 & 19.34 & 80.66 & 27.89 & 64.6 \\
\hline 1.5 & 18.65 & 81.35 & 15.63 & 78.97 \\
\hline 2.0 & 17.75 & 82.25 & 11.54 & 87.99 \\
\hline 2.5 & 16.33 & 83.67 & 6.44 & 95.52 \\
\hline
\end{tabular}

Table 6: Report of anti-inflammatory effect of water extract of Fruit of Hippophae rhamnoides and standard on HRBC membrane hemolysis and membrane stabilization.

\begin{tabular}{|c|c|c|c|c|}
\hline $\begin{array}{c}\text { Conc. of Standard/ } \\
\text { Plant Extract }(\boldsymbol{\mu l} / \mathbf{m l})\end{array}$ & \% Hemolysis & \% Stabilisation & $\begin{array}{c}\text { \% Hemolysis of } \\
\text { Diclofenac sodium }\end{array}$ & $\begin{array}{c}\text { \% Stabilisation of } \\
\text { Diclofenac sodium }\end{array}$ \\
\hline 0.5 & 32.25 & 67.75 & 47.97 & 50.9 \\
\hline 1.0 & 31.08 & 68.92 & 27.89 & 64.6 \\
\hline 1.5 & 25.18 & 74.82 & 15.63 & 78.97 \\
\hline 2.0 & 22.09 & 77.91 & 11.54 & 87.99 \\
\hline 2.5 & 17.53 & 82.47 & 6.44 & 95.52 \\
\hline
\end{tabular}

Table 7: Report of anti-inflammatory effect of DCM extract of Root of Hippophae rhamnoides and standard on HRBC membrane hemolysis and membrane stabilization.

\begin{tabular}{|c|c|c|c|c|}
\hline $\begin{array}{c}\text { Conc. of Standard/ } \\
\text { Plant Extract }(\boldsymbol{\mu l} / \mathbf{m l})\end{array}$ & \% Hemolysis & \% Stabilisation & $\begin{array}{c}\text { \% Hemolysis of } \\
\text { Diclofenac sodium }\end{array}$ & $\begin{array}{c}\text { \% Stabilisation of } \\
\text { Diclofenac sodium }\end{array}$ \\
\hline 0.5 & 41.32 & 58.68 & 47.97 & 50.9 \\
\hline 1.0 & 40.55 & 59.45 & 27.89 & 64.6 \\
\hline 1.5 & 39.12 & 60.88 & 15.63 & 78.97 \\
\hline 2.0 & 37.41 & 62.59 & 11.54 & 87.99 \\
\hline 2.5 & 29.23 & 70.77 & 6.44 & 95.52 \\
\hline
\end{tabular}

Table 8: Report of anti-inflammatory effect of Methanolic extract of Root of Hippophae rhamnoides and standard on HRBC membrane hemolysis and membrane stabilization.

\begin{tabular}{|c|c|c|c|c|}
\hline $\begin{array}{c}\text { Conc. of Standard/ } \\
\text { Plant Extract }(\boldsymbol{\mu l} / \mathbf{m l})\end{array}$ & \% Hemolysis & \% Stabilisation & $\begin{array}{c}\text { \% Hemolysis of } \\
\text { Diclofenac sodium }\end{array}$ & $\begin{array}{c}\text { \% Stabilisation of } \\
\text { Diclofenac sodium }\end{array}$ \\
\hline 0.5 & 31.23 & 68.77 & 47.97 & 50.9 \\
\hline 1.0 & 30.54 & 69.46 & 27.89 & 64.6 \\
\hline 1.5 & 26.10 & 73.90 & 15.63 & 78.97 \\
\hline 2.0 & 25.13 & 74.87 & 11.54 & 87.99 \\
\hline 2.5 & 18.21 & 81.79 & 6.44 & 95.52 \\
\hline
\end{tabular}

Table 9: Report of anti-inflammatory effect of water extract of root of Hippophae rhamnoides and standard on HRBC membrane hemolysis and membrane stabilization.

\begin{tabular}{|c|c|c|c|c|}
\hline $\begin{array}{c}\text { Conc. of Standard/ } \\
\text { Plant Extract }(\boldsymbol{\mu l} / \mathbf{m l})\end{array}$ & \% Hemolysis & \% Stabilisation & $\begin{array}{c}\text { \% Hemolysis of } \\
\text { Diclofenac sodium }\end{array}$ & $\begin{array}{c}\text { \% Stabilisation of } \\
\text { Diclofenac sodium }\end{array}$ \\
\hline 0.5 & 39.28 & 60.72 & 47.97 & 50.9 \\
\hline 1.0 & 38.76 & 59.24 & 27.89 & 64.6 \\
\hline 1.5 & 37.54 & 62.46 & 15.63 & 78.97 \\
\hline 2.0 & 34.54 & 65.46 & 11.54 & 87.99 \\
\hline 2.5 & 27.76 & 72.24 & 6.44 & 95.52 \\
\hline
\end{tabular}




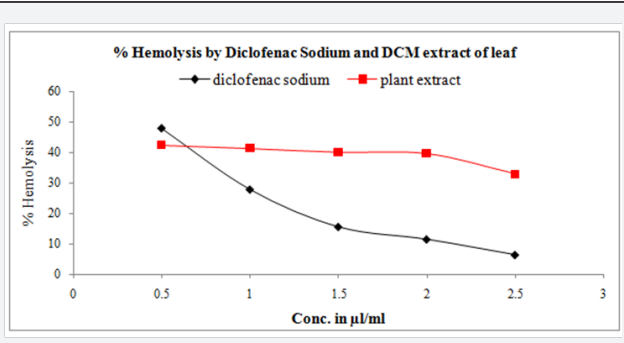

Figure 1: Graph represents HRBC Membrane Hemolysis by DCM extract of Leaf and Standard

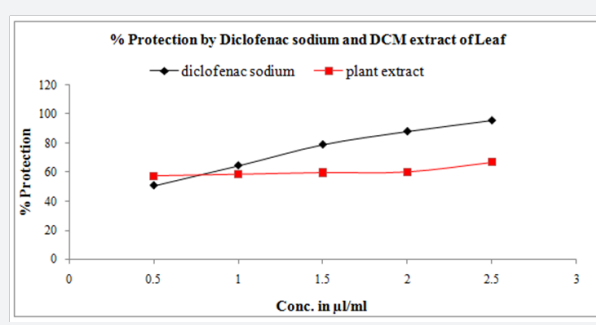

Figure 2: Graph represents the membrane \% stabilization by DCM extract of Leaf and the Standard.

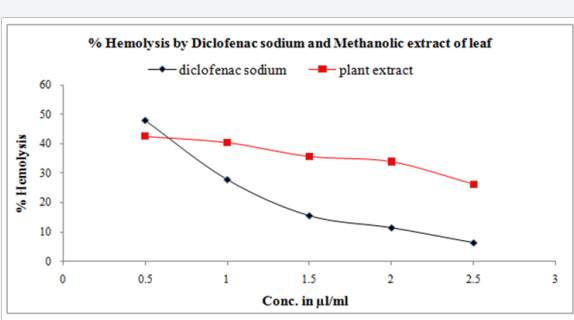

Figure 3: Graph represents HRBC Membrane Hemolysis by Methanol extract of Leaf and Standard.

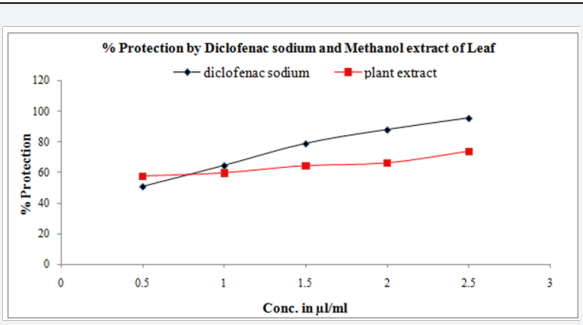

Figure 4: Graph represents the membrane \% stabilization by Methanol extract of Leaf and the Standard.

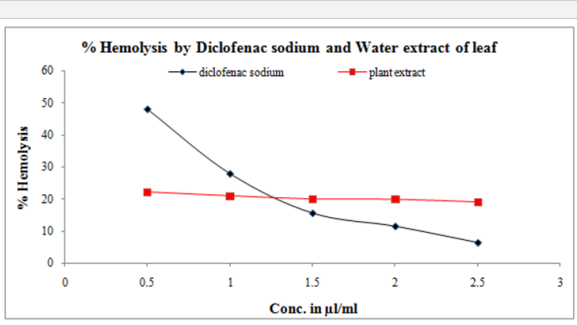

Figure 5: Graph represents HRBC Membrane Hemolysis by Water extract of Leaf and Standard.

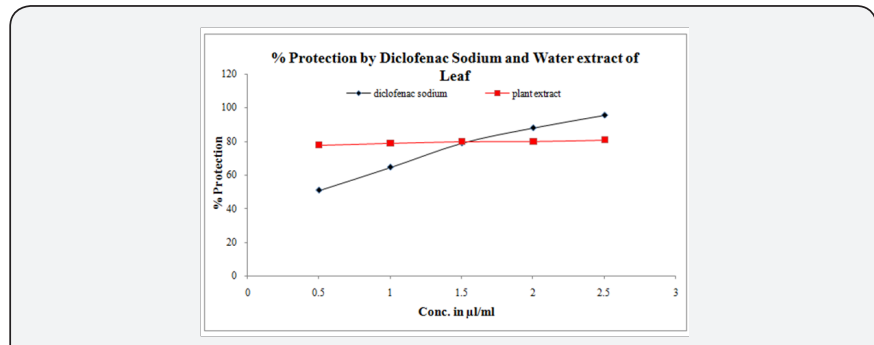

Figure 6: Graph represents the membrane \% stabilization by Water extract of Leaf and the Standard.

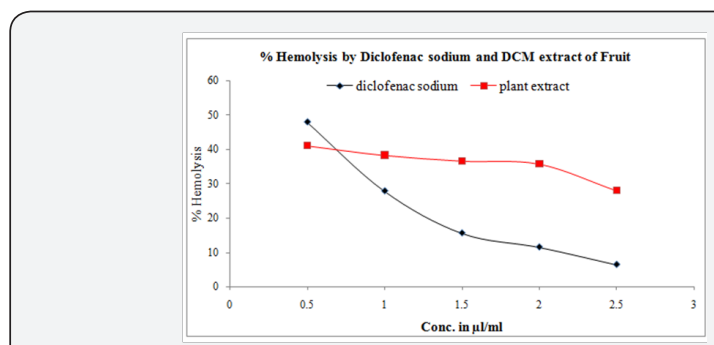

Figure 7: Graph represents HRBC Membrane Hemolysis by $\mathrm{P}$ DCM extract of Fruit and Standard.

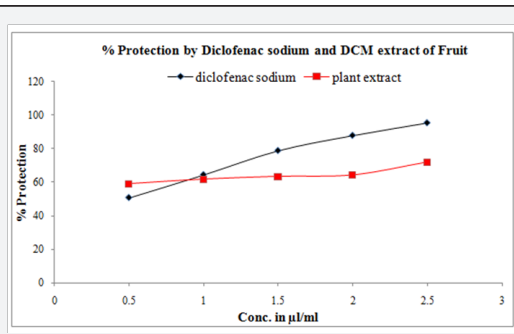

Figure 8: Graph represents the membrane \% stabilization by DCM extract of Fruit and the Standard.

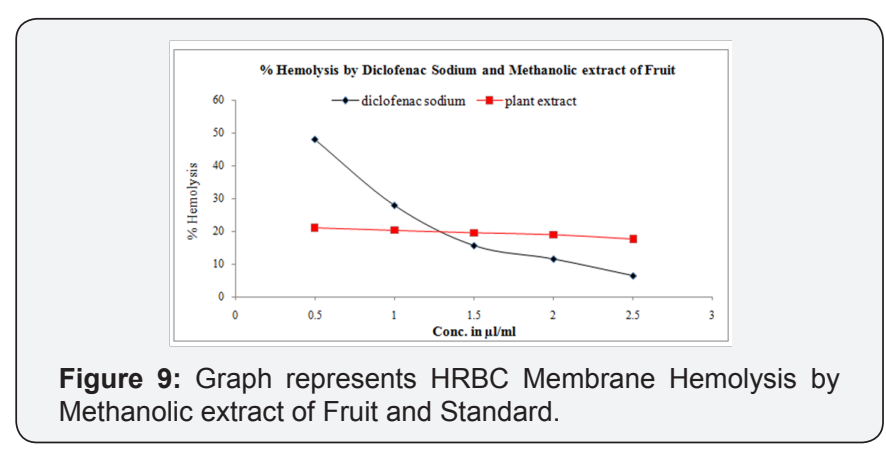

Methanolic extract of Fruit and Standard.

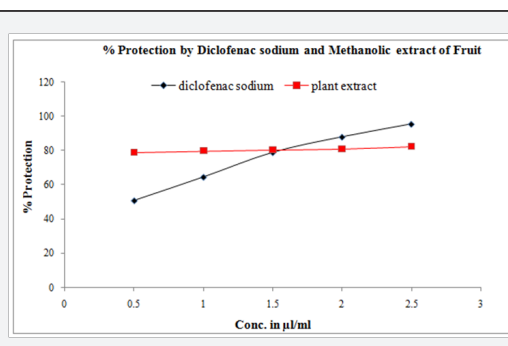

Figure 10: Graph represents the membrane \% stabilization by Methanolic extract of Fruit and the Standard. 


\section{Journal of Pharmacology \& Clinical Research}

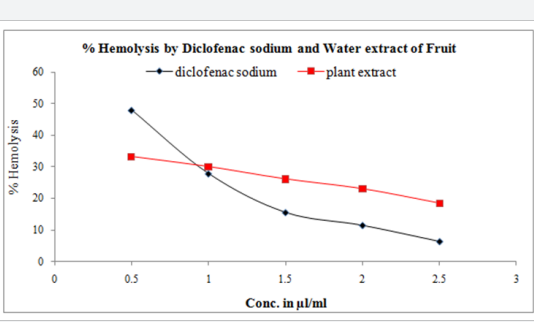

Figure 11: Graph represents HRBC Membrane Hemolysis by Water extract of Fruit and Standard.

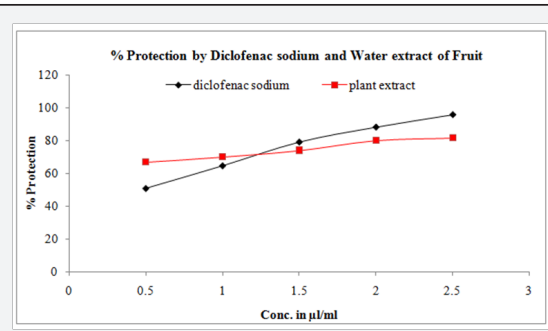

Figure 12: Graph represents the membrane \% stabilization by Water extract of fruit and the Standard.

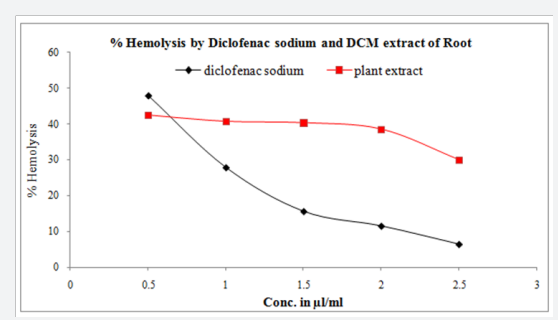

Figure 13: Graph represents HRBC Membrane Hemolysis by DCM extract of Root and Standard.
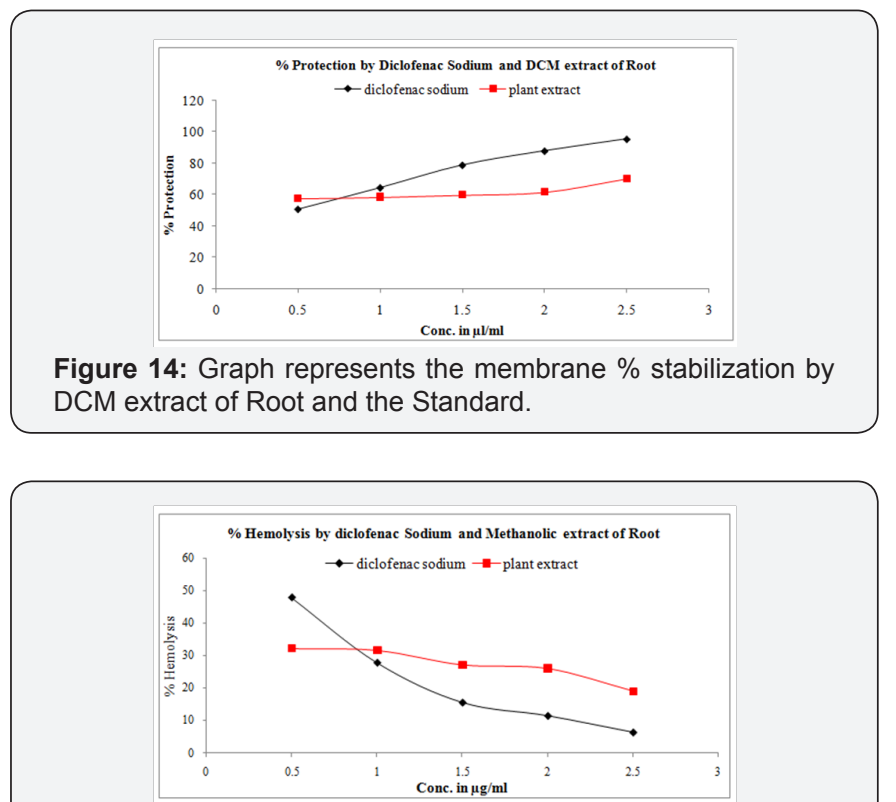

Figure 15: Graph represents HRBC Membrane Hemolysis by Methanolic extract of Root and Standard.

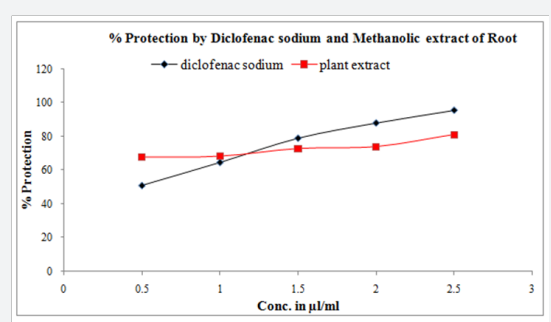

Figure 16: Graph represents the membrane \% stabilization by Methanolic extract of Root and the Standard

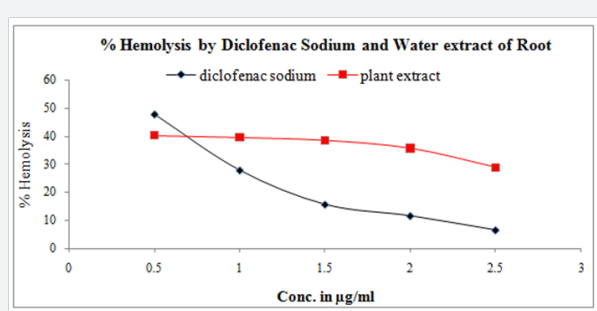

Figure 17: Graph represents HRBC Membrane Hemolysis by Water extract of Root and Standard.

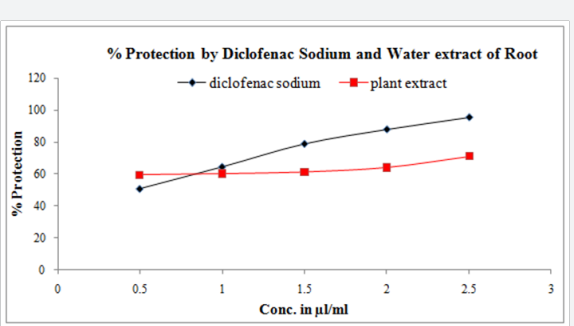

Figure 18: Graph represents the membrane \% stabilization by Water extract of Root and the Standard.

\section{Discussion}

Anti- inflammation refers to the property of a medicine or medicinal like product to inhibit the process of inflammation or swelling. Anti-inflammatory drugs make half of the analgesics, reducing pain by reducing inflammation at a particular body part of an organism. Hippophae rhamnoides plant is a well known herb used as folk medicine in North America and as home recipes for a variety of benefits, and is also used as a nontoxic herb in traditional Chinese medicine. Hippophae rhamnoides plant extracts were analysed for their anti-inflammatory effect and results obtained were found to possess a high level of effect against inflammation. The anti-inflammatory effect of plant is due to the presence of various secondary phytochemicals like flavonoids, alkaloids etc. the most enhancing capacity against the inflammation was found to be due the hemoxygenase. So the plant could be used as best anti-inflammatory source. The anti-inflammatory effect of all the plant extracts have been carried out in reference to standard diclofenac sodium (antiinflammatory drug). The inflammation was done by hypotonicity induced membrane lysis. The stabilisation against membrane induced hypotonicity was found to be concentration dependent, 
and the stabilisation percentage in all the plant extracts was found less than the reference compound (Diclofenac sodium). Among the plant extracts the highest stabilization was found in case of methanolic extract of fruit (Figure 10) followed by water extract of fruit (Figure 12). Among the all plant extracts it has been found that the polar solvent extracts posses' highest anti-inflammatory activity than the less polar solvent extracts. The results get agreed as most of the amino acids are antiinflammatory in nature so are the polar plant extracts. These compounds have direct influence upon the inflammation and the plant extracts fulfill the job in highly influenced manner. Thus Hippophae rhamnoides plant extracts can be used as best antiinflammatory medicines in addition to its already recognized properties.

\section{Conclusion}

Anti-inflammatory activity of the concerned plant is due to the presence of various types of phytochemical species. An anti-inflammatory response is the action against inflammation. From the concerned study it can be concluded that the plant bear a good potential to overcome inflammation. The antiinflammatory activity determined was found more in the polar solvents which could be due to the polar compounds extracted from the plant extracts. So overall it can be concluded that nature furnishes every source against any type of disorder.

\section{References}

1. Singh V (2005) Sea buckthorn (Hippophae L.) A Multipurpose Wonder Plant. Volume 2, Singh V Daya Publishing House, India.

2. Rajwant K Kalia, Rohtas Singh, Manoj K Rai, Gyan P Mishra, Sharbati R Singh, et al. (2011) Biotechnological Interventions in Seabuckthorn (Hippophae L.): Current Status and Future Prospects. Trees 25(4): 559-575.

3. Yan-Jun Xua, Meera Kaurb, Reshvinder S Dhillona, Paramjit S Tappiac, Naranjan S Dhalla (2011) Health benefits of sea buckthorn for the prevention of cardiovascular diseases. Journal of functional foods 3(1): $2-12$.

4. Alam Zeb (2004) Chemical and Nutritional Constituents of Sea Buckthorn Juice. Pakistan Journal of Nutrition 3(2): 99-106.

5. Sachin S Sakat, Archana R Juvekar, Manoj N Gambhire (2010) In vitro antioxidant and anti-inflammatory activity of methanol extract of Oxalis corniculata Linn. International Journal of Pharmacy and Pharmaceutical Sciences 2(1): 146-155.

6. Govindappa M, Naga Sravya S, Poojashri MN, Sadananda TS. Chandrappa CP (2011) Antimicrobial, antioxidant and in vitro antiinflammatory activity of ethanol extract and active phytochemical screening of Wedelia trilobata (L.) Hitchc. Journal of Pharmacognosy and Phytotherapy 3(3): 43-51.

\section{Your next submission with Juniper Publishers} will reach you the below assets

- Quality Editorial service

- Swift Peer Review

- Reprints availability

- E-prints Service

- Manuscript Podcast for convenient understanding

- Global attainment for your research

- Manuscript accessibility in different formats

( Pdf, E-pub, Full Text, Audio)

- Unceasing customer service

Track the below URL for one-step submission https://juniperpublishers.com/online-submission.php 